\title{
Adapting Legal Culture: Legislation and Interpretation in Tax Law
}

\author{
Asst. Prof. Dr Eda Özdiler Küçük \\ Ankara University
}

\begin{abstract}
Legal culture is defined as a way of describing relatively stable patterns of legally oriented social behaviour and attitudes. Adapting legal culture is possible, while the adapted legislation makes a shift in the social reality, especially in transition to democracy. As social behaviour depends on other elements, such as historical and cultural backgrounds of a society, the reaction for the legal adaption may differ from one country to another. So, the legislation in two countries may be the same; but the interpretation and the implementation of the law may be different. As tax norms also have an economic aspect, factors effecting the results of the tax law adaption may be historical, cultural and also economic. Adapting legal culture is more comprehensive than transplanting legal mechanisms and importing other legal systems, it is not only translating legislation but also creating a differential fitness; a different aspect of rights and principles of law design. As tax law includes social norms as well as financial norms and is a multidisciplinary branch of law, the adaption of tax law needs justification of perceived fairness and common understanding of basic law principles and rights. If the perception of law is different, the interpretation of law may create a sui generis version of the adapted law. In this article, the question to be answered is how the historical, cultural and economic factors differ adapted tax systems in practice by the interpretation of law.
\end{abstract}

Keywords: Adapting Legal Culture Legislation and Interpretation in Tax Law

\section{Introduction}

Law derives from the cultural origins of a society internally (Mautner, 2010: 844) while with legal transplants, transfering the legal and cultural perspective to other societies. This external interaction may result in social/legal development or just a shift in the social reality of the interacting culture, or may not be effective (Friedman, 1969: 40). While the success of a legal transplant, depending on the legal system of the receiving country and its culture, not impossible (Legrand: 1997), not easy (Watson: 1993), but evolutionary (Teubner, 1998: 12); it is "sui generis".

Tax law including social norms beside financial norms both of which effect human rights, reflects a society's legal culture, that is particularly called "tax culture" in literature. One can understand the perception of human rights in a society, observing the tax law in that particular country as taxation interfers a person's basic rights as life with dignity and healthy, right of property, freedom of travel etc. Taxation is also an indicator of the concept of the social state in a country, determined in the constitution and tax codes. In literature, the relationship between culture and tax law is rarely discussed while there is a lot of studies about taxation and economy. This missing part of the chain may help to understand the relationship among economy, law and culture.

\section{Reading Varga's Law-Making Cycle with Cohn's Normative Reality}

Varga, describes the creation and implementation of law in "On The Socially Determined Nature of Legal Reasoning", as (Varga, 1994: 325): 


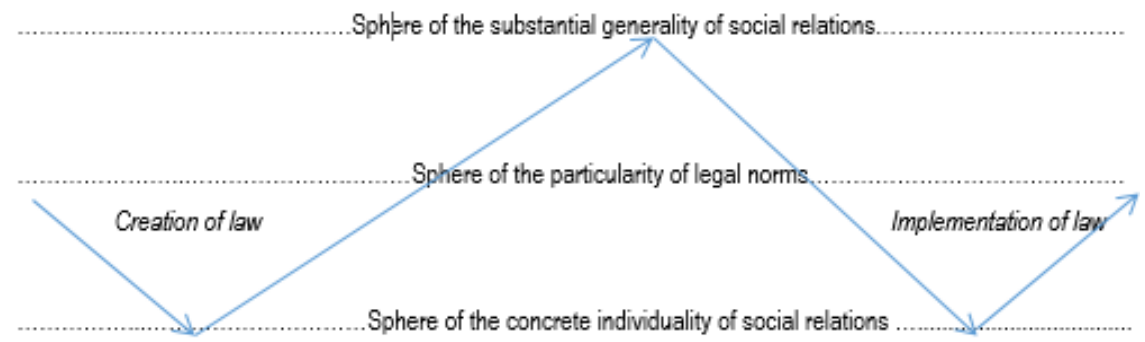

In legal dimension, there are three spheres of relations: substantial generality of social relations, legal norms and concrete individuality of social relations. Legal norms (for example a specific anti avoidance rule) are created deriving from the concrete individual social relations that present "is", (for example a tax payer's tax avoidance) while implemented according to general social relations that imply "ought" (tax legislation).

Varga explains that the sphere of social relations and the sphere of norms together form a law-making cycle:

"The motion between the general, the particular and the individual and vice versa is put together of a number of non-stop processes of transitions from the one to the other and that accordingly in this process of motion without a point of rest the segration of the various components will, surveyed from the point of view the totality of the processes of social motion, become a relative one" (Varga, 1994: 326).

As life is in constant change, laws have to keep up with the actual developments, "law is a constantly developing medium" (Kohler, 1914: 4-7, 32). Tax norms effect people's economic states and they are always changed according to the economic necessities, they can be called "dynamic rules" (Hage, 2016: 37). As the conditions, people's choices thus "is" change, the perception of "ought" also change. This interaction creates a cycle of reality between "is" and "ought". Law in general and tax law in particular, determines a normative reality in between the spheres "ought" and "is" (Cohn, 1967: 68). So, "is" does not stand "versus" "ought"; on the contrary, "is" becomes a "part" of "ought". When there is a shift in the social reality, for example a social development, transition to democracy, or an economic crises, there is a social pressure for a legal reform.

\section{Fact and Value: A Dualism or A Dichotomy}

Suggesting that it is not possible to derive ought-sentences from is-sentences; Hume said "there is an unbridgeable chasm between the world of fact and the world of value" (Hume: 1978). Kelsen made the distinction between facts and norms one of the starting points of his pure theory of law (Kelsen: 1934). He also stated that norms belong to the realm of "ought" (Kelsen, 1934: 72). Habermas separated the facts and norms as the duality of modern law and named law as a social mediator between facts and norms (Habermas, 1996: 1). On the other hand, Searle explained how to derive "ought" from "is" (Searle, 1964: 43-58) and Putnam opposed the distinction between facts and values which he called "fact/value dichotomy" (Putnam, 2002: 7-45).

These views may seem in opposition, however, they all accept the relationship among facts, norms and values. For example, Habermas draws a sharp distinction between universal ethical norms and non-universalizable values and argues that only the "norms" are objective. Discourse ethics is characterized by a sharp distinction between values and norms, but not on the level of values (Joas, 2001:3). The problem is where to put "values" in the creation and implementation of law.

Values as well as facts, belong to the "sphere of the concrete individuality of social relations" in social reality and therefore in the realm of "is" in Varga's picture. Norms and laws belong to the realm of "ought", deriving from the facts that has an influence of values.

Modern tax law, solid with Kelsen's pure theory of law and hierarchy of norms (Kelsen, 1934), maintains legality principle. However ethical norms -derive from the values of a culture and do not have a sanction- also exist in tax codes, tax regulations or codes of conduct, in line with taxpayer's rights. It is common that there are also a lot of social norms in tax codes. Tipke differentiates norms in tax law according to their purpose, as "Finanzzwecknormen" (norms with financial purpose) und "Socialzwecknormen" (norms with social purpose). First are the norms that aim to collect tax where the second type of norms are the results of social, cultural, scientific and health etc. policies (Tipke, 1983: 17-21). 
Kohler argued in his major book, Philosophy of Law, that the supreme vocation of humanity is to promote and develop culture and the function of law is to facilitate the realization of this human vocation. According to him, law can achieve that function by preserving human values that are worthy of preservation, by creating continuity and stability with regard to such values, by allowing human beings to create viable institutions for cooperative action (Kohler, 1914: 12). Human values are observed in human rights, in principles of national and international law. Equality is a value for example, exists in national and international laws, as well as tax laws, as a principle in the Constitutions and in various legal forms in tax codes such as the progressive income taxation.

\section{Legal Culture and Legal Transplants}

It is an often asked question that, is law derives from the culture or culture derives from the law? It can be said that both proposals are true.

There is an endless cycle between culture and law, internally and externally. It is a dynamic relation that shapes the legal, social and economical system of a society, which also draws the internal evolutional structure.

Van Hoecke \& Warrington emphasises that "law is more than just a set of rules or concepts. It is also a social practice within a legal community. It is this social practice which is determining the actual meaning of the rules and concepts, their weight, their implementation, and their role in society" (Van Hoecke \& Warrington, 1998: 5)

It is no longer disputed that legal culture is both a cause and effect of law: on the other hand, it shapes the essential basic ideas of a national legal order, while on the other hand it is constantly exposed to legal influences (Gessner, 1993: 5). Legal culture is defined as a way of describing relatively stable patterns of legally oriented social behaviour and attitudes (Nelken, 2004: 1)

Bell defines legal culture as "a specific way in which values, practices, and concepts are integrated into the operation of legal institutions and the interpretation of legal texts" (Bell, 1995: 70). In line with this definition, Friedman describes the legal culture on the components of the legal system (Friedman, 265, 266). According to Friedman, a legal system is formed of three components, which are structural, cultural and substantive components. Structural components refer to the institutions whereas cultural components are the values and attitudes which bind the system together, and which determine the place of the legal system in the culture of the society as a whole. Substantive components are the laws themselves. These three elements together - structural, cultural, and substantive - make up the legal system; while structural and cultural components form the legal culture. Legal cultures differ legal systems which are a part of political, social and economic development (Friedman, 262). So, according to Friedman's definition of legal culture, we can say that legal transplants harmonize the substantive components, but not legal systems as a whole. As Legrand says, "a rule does not have any empirical existence that can be significantly detached from the world of meanings that characterizes a legal culture; the part is an expression and a synthesis of the whole" (Legrand: 6).

Based on Friedman's definition, a legal system can be divided into three components, as jurisdiction, law and culture:

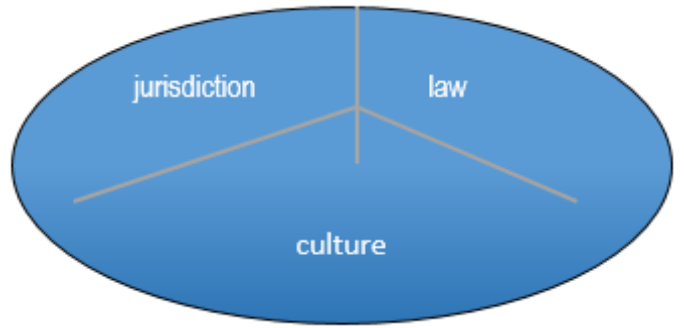

When a new norm is transplanted in the legal system, it makes a shift in both social and normative realities. It both effects the creation and the implementation of the legal system. 


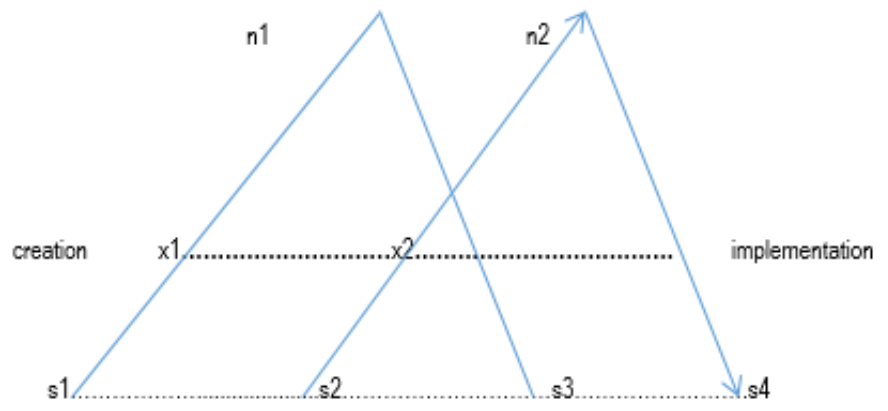

In the scheme above, the plane "s" refers to social reality in a society, while the plane " $n$ " refers to normative reality. The creation of law begins with the facts and values of the society and forms a norm (x1) and finds its places in the legislation (n1) according to its hierarchic place. The norm is implemented in line with the constitution and principles of law. If the norm is against the constitution or if the norm does not constitute the social reality, it will be cancelled or deviated in implementation (s3). This is the self-evolution of a legal system, which may be called "internal evolution" (Nelken, 2004: 22).

When a norm (x2) is adapted in a legal system, it will be a norm derived from another culture's values and facts (s2), subject to another legislative hierarchy (n2) and another social reaction (s4). This "external evolution" (Nelken, 2004: 22) makes a shift in both social reality (s3 to $\mathrm{s} 4$ ) and normative reality ( $\mathrm{n} 1$ to $\mathrm{n} 2$ ).

The legal transplant may derive from another country's legislation or an international organization as OECD or EU. Anti avoidance tax programmes of these organizations are very actual; OECD's BEPS (base erosion and profits shifting) agenda and ATA (anti tax avoidance) Directive of EU are examples of international legislation implemented to national laws. However national legal transplantations are also very common in history. It is not always a norm that is adapted, but mostly codes.

For example, if a developing country's economy mostly depends on international investment (s1), so it does not have an efficient anti avoidance norm (x1) and a constitutive protection (n1); when it adapts a BEPS rule (x2), changing its constitution (n2), not being a tax heaven anymore may result with a gap in the budget (s4) or a better tax system (s4) (It depends on the circumstances).

According to Legrand, "a rule's very existence depends on its interpretation and application within an interpretative community and this is historically and culturally conditioned" (Legrand, 1997). This is rather true for national legal transplants. For example, if a tax code is adapted from another country (x2), this needs civil law and constitutional law reforms (n2), too; which will certainly change the social reality ( $\mathrm{s} 1$ to s4). Even than the "interpretation and application" will not be the same as the original legal culture. However, this legal adaption cannot be called unsuccessful or impossible. It is not the same legal culture that develops, but another version of the donor legal culture; a sui generis legal culture, different than its origin.

\section{The Reasons Why Adapted Tax Laws Differ in Implementation}

Adapted legal culture is different in the host than the donor, as Watson says, "the legal transplant will take on a life of its own in its new host" (Watson, 1993). What are the reasons of this difference and particularly in the case of tax law?

\subsection{Garbarino's Evolutionary Approach}

Garbarino, explains the differences between the tax systems with an evolutionary approach. According to him, "at a given moment in time a tax system has a structure identifiable through a model of tax systems in terms of hierarchies of rules, and the evolution of tax systems is constrained by their structure" (Garbarino, 2010: 773). Based on hierarchies of tax rules, he explains the evolutionary structure of tax systems.

The idea that law has a hierarchical structure is first introduced by Kelsen and typically advanced by legal positivism (Kelsen, 1945). Garbarino bases his argument on formal hierarchy, which he describes as, 
"a "formal hierarchy" is one which obtains between a rule on production (R1) and a produced rule (R2), when a rule of production $(R P)$ establishes how $R 2$ is produced. $R 1$ is therefore superior to $R 2$. A formal hierarchy is a relation between a (higher secondary) rule $R 1$ and a lower rule $R 2$... Whenever a produced rule $R 2$ is created according to a rule on production, there is a "chain of production" of rules. The process of creation of tax rules occurs through "chains of production" and the operation of formal hierarchies shows that different tax systems share a common structure based on chains of production, regardless of the prescriptive content of the rules and irrespectively of the subtleties of different legal cultures" (Garbarino, 2010: 775, 777)

As the process of creation of tax rules occur through "chains of production", adapting a norm/code needs a harmonization of other related parts of the legislation chain. If the donor legal system belongs to the same legal family for example, European law family, the adaption will be more successful than in another legal family. A legal transplant should not be against the constitution in the new host, therefore it is not only a norm that is changed, but a constitutive arrangement may be necessary or simply it cannot be transplanted. The lower regulations in the hierarchically order should also be changed according to the new rule. Even if the other parts of the chains are the same, the two legal cultures would not be the "same"; they would be "similar", because of the differences in practice.

If a tax norm/code is adapted from another country, even if the constitutions have the same taxation principles, with a similar normative structure, the practices could be different, depending the legal cultures of the countries.

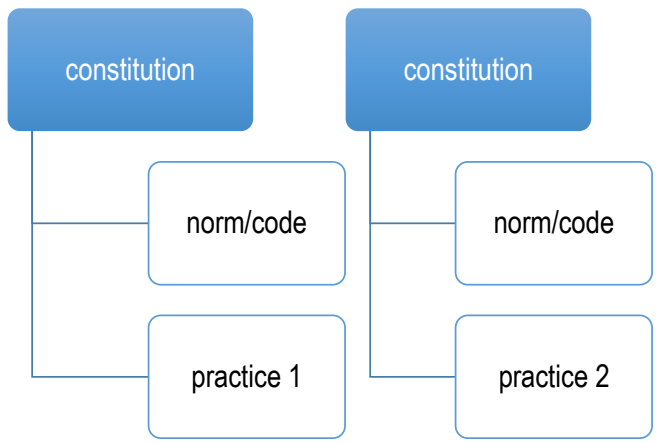

Hierarchic structure of legal cultures is insufficient to explain the differences between two legal cultures. Remembering Garbarino's "evolutionary structure" argument, the question why adapted tax systems differ can be explained by the factors that play role in the evolution of a tax system. These factors can be historical, cultural, economic and institutional.

\subsection{The Example of Turkey and Germany}

Turkey and Germany is a good example of legal transplantation. Turkey has adapted the Personal and Corporation Income Tax Codes and the Tax Procedure Code from Germany, and has been successful in implementation. However, with the same taxation principles and legal transplantations, these two countries had different implementations of the same legislation, depending on their structural evolution. The factors that differentiate their evolutional structure can be explained on the subject of "ability to pay principle":

\subsubsection{Factors of Differentiation}

The Turkish Personal Income Tax Code was codified from the German Personal Income Tax Code in 1961, that is why the concept of income tax is mostly alike. As the main legal structure of these two systems are the same, in implementation, they differ in terms of "non-disposable income" which is also called as "deduction of inevitable personal expenditure" or "safeguarding subsistence level" in literature (Tipke, 1993: 672-692; Tipke\&Lang, 1996: 73) and "the taxable income" in jurisprudence (as BverfG of 3 Nov. 1982, I R 3/79) in line with Tipke's emphasis on the difference between "economic capacity" and "taxable capacity" in the use of ability to pay principle (Tipke, 1993: 480, 481). According to the writer, "economic capacity" is about the total income whereas "taxable capacity" is about the income above the subsistence level; so the ability to pay principle determines "the taxable income". 
Since Article 1 of the German Constitution (Grundgesetz) protects human dignity, in 1992 the German Federal Constitutional Court (Bundesverfassungsgericht) ruled that taxpayers have the constitutional right to a basic personal exemption equal to the subsistence amount which welfare services have to guarantee constitutionally to people without income as a minimum civilized standard of living. In German tax law, it is accepted that the expenses for private consumption which are "unavoidable" decrease the ability to pay so only the income above the subsistence amount may be taxed (BVerfG of 29 May1990, 1BvL 20/84).

In contrary with this, in Turkish tax law, "the taxable income" is found at the end of various deductions mostly in commercial business and freelance incomes but a few with the wage income. Cost-of-living allowance is only for wage earners and it is under subsistence level. The expenses for private consumption which are "unavoidable" are included in the taxable income. The progressive income tax tariff begins with a zero-bracket amount and has ineffective ratios. The income tax tariff does not take the marital status into consideration. These factors differ the concept of "taxable income" in these two tax law systems. How did these income tax codes differ on the basic concepts in time, one original and the other one adapted, with the same constitutional principles? Why does a basic taxation principle differ in tax systems in implementation? These questions has three answers, historical, cultural and institutional.

Taxation is regulated in the 73th Article of Constitution of 1982 in Turkey. Although ability to pay principle is clearly maintained in this article, The Turkish Constitutional Court (for ex. 1994/84,18/07/1995) and literature (Öncel\&Kumrulu\&Çağan, 2016: 280) mostly explains this principle with social state principle (Art. 2) but not with right to equality (Başaran Yavaşlar, 2011:62,63) or with human dignity as in German law. This is because of the juidicial minds in these legal cultures are different. Juidicial mind and jurisdiction is a part of the legal culture. In this example, after the legal transplantation, German tax system continued its self evolution and a part of its legal system, German Federal Constitutional Court established a connection between human dignity and taxable income, which resulted with a change in the German Income Tax Code. Building this relationship was also about the perception of human rights. So the reason of the differentiation was not only institutional (about jurisdiction), but also about legal history.

The German Federal Constitution was accepted in 1949, after the Second World War, making human rights and human dignity central and core part of a legal reform. The components of the German Federal Constitution were the principles of democracy, republicianism and social responsibility (Seiler, 2016: 21). This emphasis of human dignity in the Constitution and Tipke's differentiation of "economic income" and "taxable income", emerged the idea "that taxpayers have the constitutional right to a basic personal exemption equal to the subsistence amount which welfare services have to guarantee constitutionally to people without income as a minimum civilized standard of living", in juidicial mind.

The concept of "protective state" was emphasized by Alex Tocqueville in 1830s and put into legislation in Bismarck Germany in 1800s. This concept was legislated in Turkish law first in 1937 in the Constitution of 1924 as "statism". This delay of about a hundred years caused a differentiation in the legal culture about the perception of social state. Unlike the first decades of the Republic, the understanding of "social state" developed slowly in Turkey, due to the socio-economic policies, even the social state principle is under Constitutional protection. As a result, progressive income taxation became the only method for the implementation of ability to pay principle, which does not fully establish the principle of equality, used with ineffective ratios and zero bracket amount. Even though human dignity is protected constitutionally in Art. 17 of the 1982 Constitution, it is not systematically in the central; however it was still possible for the jurisdiction to establish this relationship, while it is being discussed in literature (Özdiler Küçük: 2016).

Of course, the perception of ability to pay principle is different, when the meaning of taxable income is different. "The meaning of the rule is an essential component of the rule" (Legrand, 1997: 114); therefore two rules with different meanings are two different rules. Taxable income is the heart of an income tax code. Two income tax codes with different taxable income definitions cannot be called the same, even if one is adapted from the other, they can be called systematically alike. However this does not mean that the adaption was unsuccessful, or adapting legal culture is impossible. It is possible, it may not transform a legal culture but it certainly makes a difference. That is the case for German and Turkish Income Tax Codes. The donor legal system continued its self evolution deriving from its own social and normative realities (war and a major legal reform) while the recipent legal system evolved with its own realities (economic development and legal reforms) in a sui generis way according to the interpretation of its own juidicial mind. Today, as the German tax system walked the first steps of dual income taxation by excluding capital income from the income tax tariff and taxing capital income at a 
lower final withholding tax rate, Turkey has a Draft Code of Income Tax, which still maintains progressive taxation, but merging personal income tax and corporation income tax in one code, while flat taxation is being discussed in academia.

\subsubsection{Interpretation and Judicial Mind}

Kelsen, calls interpretation as the "cognitive ascertainment of the meaning of the object" and emphasizes on the limits of interpretation:

"... the result of a legal interpretation can only be the ascertainment of the frame which the law that is to be interpreted represents, and thereby the cognition of several possibilities within the frame. The interpretation of a statue, therefore need not necessarily lead to a single decision as the only correct one, but possibly to several, which are all of equal value, though only one of them in the action of the law-applying organ (especially the court) becomes positive law" (Kelsen, 1967: 351).

Legrand, on the other hand, calls interpretation a "subjective and cultural product" and defines it as "the result of a particular understanding of the rule that is conditioned by a series of factors which would be different if the interpretation had occurred in another place or in another era" which is "the outcome of an unequal distribution of social and cultural power within society as a whole and within an interpretive community in particular" (Legrand, 1997: 115).

Reading these two definitions together it can be concluded that, legal culture is a reason of choice of the interpretation method among the possibilities that exist within the framework of that particular law. The difference between the decisions of German Federal Constitutional Court (Bundesverfassungsgericht) and Turkish Constitutional Court on ability to pay principle may constitute an example for the choice of the interpretation method according to the juidicial mind and the legal culture.

The Turkish Tax Procedure Code, originating from the Reich Fiscal Code, but following a different legal development, shows the background and an alternative version of the German General Tax Code. Turkish Tax Procedure Code No. 213 is in operation since 1961, first version of which was mostly adapted from the Reich Fiscal Code. Interpretation was regulated in the Sec. 4 and 5 of Reich Fiscal Code in German tax law, methods of interpretation in the $4^{\text {th }}$ and general anti avoidance rule on the $5^{\text {th }}$ Sections. In Germany, after the Second World War, there was a major tax reform in 1977 which changed the Sec. 5 of the Reich Fiscal Code- that included the general anti avoidance rule- into Sec. 42 of the German General Tax Code. Turkish Tax Procedure Code Art. 3, regulates many important tax law subjects within, which are interpretation, a general anti abuse clause, proof in tax law and burden of proof. Rule of interpretation of tax norms were added in the TTPC Art. 3 in 1980, as "Tax acts are effectual with their literal and spiritual construction. When letters of act are not clear, tax law decrees will be enforced according to the aim they were prepared for, their place in the structure of law and their connection with other articles"; in line with the interpretation rule in traditional German tax law, in Sec. 4 of the Reich Fiscal Code which explained the methods of interpretation as, "when interpreting tax legislation, its purpose, its economic significance and developments in circumstances are to be taken into account" and the general anti avoidance rule representing perspective.

These interpretation methods are in fact parallel with the Kelsen's methodology of interpretation. Kelsen, in his book Pure Theory of law, describes these methods as;

"The legal act applying a legal norm may be performed in such a way that it conforms,

with the one or the other of the different meanings of the legal norm,

with the will of the norm-creating authority that is to be determined somehow,

with the expression which the norm-creating authority has chosen,

with the one or the other of the contradictiory norms, or

the concrete case to which the two contradictiory norms refer may be decided under the assumption that the two contradictiory norms annul each other." (Kelsen, 1967: 351)

In both Turkish and German tax systems the interpretation methods are the same; literal, historical, teleological, systematical interpretation and economic perspective. While the literal interpretation has a priority to other methods, courts may not refer to the wording of a law, consider its purpose with teleological interpretation. Sometimes the court decides 
with the historical development of a legal provision which means the historical interpretation. It may refer to the place of their place in the structure of law as systematical interpretation or to the economic significance with an economic perspective.

So the question is, for the same problem of law, how may the courts of the donor and the recipient legal systems react, how do they interpret for the same case, with the same legislation and the same interpretation rules? In the case of interpreting ability to pay principle, German Federal Constitutional Court and the Turkish Constitutional Court processed systematical interpretation, both referring to their Constitutions, ending with different conclusions. Judicial mind is a part of legal culture, and referring to Kelsen, in the framework of legislation, the possibilities of interpretation is maintained by the legal culture. As Marmor says, "interpretation is a part of the legal practice" (Marmor, 2005: 45).

\section{Conclusion}

In the case of legal transplantation, the success of a legal transplant depends on the legal system of the receiving country and its legal culture. As a component of a legal system, legal culture has a determinant character in the development of a tax system. Interfering with a norm externally in a legal system, makes a reaction in both the social and normative realities, in means of law making and interpretation. This reaction is sui generis, according to the legal culture of the country. Historical, cultural and institutional factors are effective in maintaining the interpretation of the legislation and on the judicial mind. As the culture is determinant in the law making process and its validation, law has its shape as a fluid in the glass of culture, while also determining the color of the fluid in the glass.

\section{References}

[1] Başaran Yavaşlar, Funda (2011), Gelir Vergilendirmesinin Temelleri, Seçkin, İstanbul.

[2] Bell, John (1995), "English Law and French Law - Not So Different?", Current Legal Problems, Vol. 48, 63-101.

[3] Cohn, Georg (1967), Existentialism and Legal Science, translated by george H. Kendal, Oceana Publications, New York.

[4] Friedman, Lawrence M. (1969), Legal Culture and Social Development, Law\&Society Review, Vol. 4, No. 1, Aug., 29-44.

[5] Habermas, Jürgen (1996), Between Facts and Norms, Contributions to a Discourse Theory of Law and Democracy, translated by William Rehg, MIT Press, Cambridge, Massachusetts.

[6] Hage, Jaap (2016), "Facts, Values and Norms" in ed. Sanna Taekema, Bart van Klink, Wouter de Been, Facts and Norms in Law, Interdiscipliniary Reflections on legal Method, EE Publishing, USA.

[7] Joas, Hans (2001), "Values versus Norms: A Pragmatic Account of Moral Objectivity", in the Hedgehog Review $3,42-56$.

[8] Garbarino, Carlo (2010), "Comparative Taxation and Legal Theory: The Tax Design Case of the Transplant of General Anti-Avoidance Rules", Theoretical Inquiries in Law 11.2, 760-790.

[9] Gessner, Volkmar (1993), "Wandel europäischer Rechtskulturen" in Bernhard Schäfer (ed.), Lebensverhältnisse und Konflikte im neuen Europa, Frankfurt-am-Main: Campus, 5-18.

[10] Habermas, Jürgen (1996), Between Facts and Norms, Contibutions to a Discourse Theory of Law and Democracy, translated by William Rehg, The MIT Press, Cambridge Massachusetts, Second Printing.

[11] Kelsen, Hans (1934), Introduction to the Problems of Legal Theory, A Translation to the First Edition of the Reine Rechtslehre, translated by Bonnie Litschewski Paulson and Stanley L. Paulson, 1997 Clarendon Paperbacks.

[12] Kelsen, Hans (1945), General Theory Of Law And State, translated by Anders Wedberg, Harvard University Press, Cambridge Massachusetts, Third Printing 2009, The Lawbook Exchange Ltd, Clark, New Jersey.

[13] Kelsen, Hans (1967), The Pure Theory of Law, Translation from the $2^{\text {nd }}$ Ed. By Max Knight, $5^{\text {th }}$ Ed. 2008, The Lawbook Exchange Ltd. 
[14] Kohler, Josef (1914), Philosophy of Law, Adalbert Albrecht trans. Augustus M. Kelley.

[15] Lang, Joachim (1999), "Chapter 4: Germany”, in M. T. Soler Roch (ed.), Family Taxation in Europe, Kluwer Law International, 55-71.

[16] Legrand (1997), "The Impossibility of Legal Transplants", Maastricht Journal, Eur\&Comp. L. 113, 111-124.

[17] Marmor, Andrei (2005), Constructive Interpretation and the Principle of Charity, Second Edition, Oregon Hart Publishing, Oxford and Portland.

[18] Mautner, Menachem (2010), "Three Approaches to Law and Culture”, Cornell Law Review, 96, p. 839-867.

[19] Nelken, David (2004), "Using the Concept of Legal Culture", 29 Austl. J. Leg. Phil. 1, 1-26.

[20] Öncel, Muallâ / Kumrulu, Ahmet / Çağan, Nami (2016), Vergi Hukuku, 25. Bası, Turhan, Ankara.

[21] Özdiler Küçük, Eda (2016), "Taxation of Family Income in Turkey: Reconsidering Distributive Measures", Hacettepe Law Review, 6 (1), 63-76.

[22] Putnam, Hilary (2002), The Collapse of the Fact/Value Dichotomy and Other Essays, Harvard University Press, England.

[23] Searle, John (1964), "How to Derive "Ought" from "Is", Philosophical Review 73 (1), 43-58.

[24] Tipke, Klaus (1983), Gerechte Steuern Geordnete Besteuerung, DStG, Köln.

[25] Tipke, Klaus (1993), Die Steuerrechtsordnung, Band. I, 2. Auflage 2000, Otto Scmidt Verlag, Cologne.

[26] Tipke, Klaus/Lang, Joachim (1996), Steuerrecht, 22. Auflage 2015, Otto Schmidt Verlag, Cologne.

[27] Van Hoecke, Mark \& Warrington, Mark (1998), "Legal Cultures, Legal Paradigms and Legal Doctrine: Towards a New Model for Comparative Law", The International and Comparative Law Quarterly, Vol. 47, No. 3, 495-536.

[28] Varga, Csaba (1994), "On The Socially Determined Nature of Legal Reasoning", Law and Philosophy, Selected Papers in Legal Theory, Budapest, 317-78.

[29] Watson, Alan (1993), Legal Transplants, $2^{\text {nd }}$ ed., University of Georgia Press. 